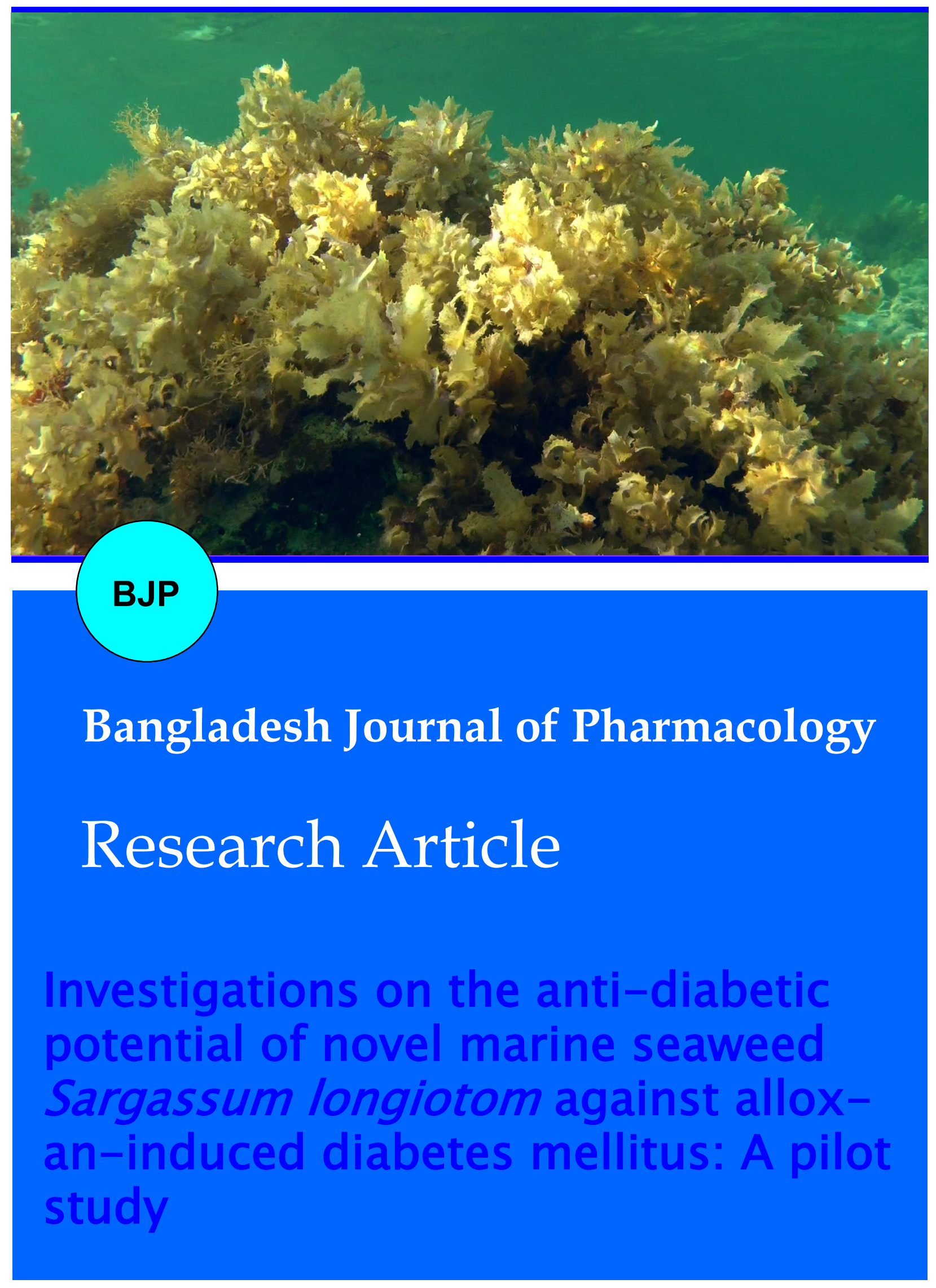


Abstracted/indexed in Academic Search Complete, Agroforestry Abstracts, Asia Journals Online, Bangladesh Journals Online, Biological Abstracts, BIOSIS Previews, CAB Abstracts, Current Abstracts, Directory of Open Access Journals, EMBASE/Excerpta Medica, Google Scholar, HINARI (WHO), International Pharmaceutical Abstracts, Open J-gate, Science Citation Index Expanded, SCOPUS and Social Sciences Citation Index

\title{
Investigations on the anti-diabetic potential of novel marine seaweed Sargassum longiotom against alloxan-induced diabetes mellitus: A pilot study
}

\author{
Stalin Selvaraj ${ }^{1}$ and Sampathkumar Palanisamy² \\ ${ }^{1}$ Centre for Nanotechnology \& Advanced Biomaterials, School of Chemical \& Biotechnology, SASTRA University, \\ Thanjavur, India; ${ }^{2}$ Department of Chemistry \& Biosciences, Srinivasa Ramanujan Centre, SASTRA University, \\ Kumbakonam, India.
}

\begin{tabular}{|c|c|}
\hline \multicolumn{2}{|l|}{ Article Info } \\
\hline Received: & 11 December 2013 \\
\hline Accepted: & 18 March 2014 \\
\hline Available Online: & 23 April 2014 \\
\hline \multicolumn{2}{|c|}{ DOI: 10.3329/bjp.v9i2.17304 } \\
\hline $\begin{array}{l}\text { Cite this article: } \\
\text { Selvaraj S, Palan } \\
\text { tions on the anti- } \\
\text { novel marine S } \\
\text { longiotom against } \\
\text { betes mellitus: A } \\
\text { desh J Pharmacol. }\end{array}$ & $\begin{array}{l}\text { samy S. Investiga- } \\
\text { liabetic potential of } \\
\text { aweed Sargassum } \\
\text { lloxan-induced dia- } \\
\text { ilot study. Bangla- } \\
\text { 2014; 9: 194-97. }\end{array}$ \\
\hline
\end{tabular}

\begin{abstract}
The present study evaluated the hypoglycemic effect of brown algae Sargassum longiotom in alloxan-induced diabetic rats. After the treatment with S. longiotom extract, there is a significant reduction $(\mathrm{p}<0.001)$ in blood glucose when compared with the diabetic control group. Moreover the ethanolic extract of $S$. longiotom significantly reduces $(p<0.001)$ the levels of triglycerides, low-density lipoprotein cholesterol and very low-density lipoprotein cholesterol dose-dependent manner. Alternatively, it increases the high-density lipoprotein cholesterol level in the treated groups. The values of SGOT, SGPT and ALP have been significantly reduced $(p<0.001)$ in the treated rats when compared to diabetic control. Thus the present study indicates that the ethanolic extract of seaweed S. longiotom posses very effective hypoglycemic and hypolipidemic effect on the alloxan induced diabetic rats compared to the reference drug glibenclamide.
\end{abstract}

\section{Introduction}

Diabetes mellitus is one of the most dreadful endocrine disorders. It has a significant impact on human health, life expectancy of the patients suffered by diabetes mellitus (Alberti and Zimmet, 1998). According to WHO report, every year the incidence of diabetes mellitus is dramatically increased so WHO made an attempt to reduce the burden of diabetes mellitus by the use of traditional medicine systems. Several reports in the literature indicated that plant phytochemicals such as flavonoids and alkaloids possess excellent antidiabetic effect by increasing insulin secretion and activating several metabolic pathways related to carbohydrate metabolism which is comparable with the commercial available allopathic drugs like metformin (Dembinska-Kiec et al., 2008). Because of the scarcity of medicinal plants availability and more need for new molecules for the treatment of diabetes mellitus, scientist paid more attention for the use of other natural source like the plants in the ocean.

Ocean posses several biological active compounds which are helpful for the discovery of novel molecules for the treatment of hormonal based disorders such as cancer, diabetes, arthritis etc., Ocean weeds has maximum nutritional value that can be used as dietary protein supplement for the treatment of protein malnutrition conditions (Aravindan et al., 2013; Guerra Dore et al., 2013). Sargassum longiotom (S. longiotom) is large brown seaweed of the division Phaeophyta. The hypolipidemic effect has been studied by several workers, however, there exists meager studies on the antidiabetic potential of S. longiotom. Hence, this study has been taken up to identify the antidiabetic potential of $S$. longiotom. 


\section{Materials and Methods}

\section{Sample collection and preparation of the extract}

The brown algae S. longiotom were collected from Thonithurai, Mandapam, South coast of India. The Samples were dried under shade at room temperature, pulverized by a mechanical grinder and sieved through 40 meshes. The powdered material (100 g) was extracted with $99.9 \%$ ethanol by a cold percolation method in a Soxhlet apparatus. The extract was then concentrated and dried under reduced pressure. The ethanol free semi solid mass obtained was used for the experiment.

\section{Animals}

Healthy Swiss albino rats of 6-8 weeks age and of either sex, weighing 150-180 g, were used. The animals were kept in clean and dry plastic cages, with $12 / 12$ hours light/dark cycle at $25 \pm 2{ }^{\circ} \mathrm{C}$ temperatures and $45-55 \%$ relative humidity. The animals were fed with standard pellet diet (Gold Mohor rat feed; M/S Hindustan Leaver Ltd, Mumbai) and water was given ad libitum.

\section{Induction of experimental diabetes}

A single dose $(150 \mathrm{mg} / \mathrm{kg}$ body weight, i.p.) of alloxan monohydrate (1\%, SD Fine Chemicals Pvt. Ltd., Biosar) dissolved in sterile normal saline was used for induction of diabetes mellitus in the rats. Diabetes was con-

\begin{tabular}{|c|c|c|c|}
\hline \multicolumn{4}{|c|}{ Table I } \\
\hline \multicolumn{4}{|c|}{$\begin{array}{l}\text { Effect of ethanolic extract of S. longiotom on blood } \\
\text { glucose }\end{array}$} \\
\hline \multirow[t]{2}{*}{ Groups } & \multicolumn{3}{|c|}{ Treatment days } \\
\hline & 1 & 10 & 21 \\
\hline $\begin{array}{l}\text { Control } \\
\text { (Normal saline) }\end{array}$ & $\begin{array}{l}91.6 \\
(7.4)\end{array}$ & $\begin{array}{l}91.8 \\
(8.5)\end{array}$ & $\begin{array}{r}92.0 \\
(7.9)\end{array}$ \\
\hline $\begin{array}{l}\text { Diabetic control } \\
\text { (Alloxan } 150 \mathrm{mg} / \mathrm{kg} \text { ) }\end{array}$ & $\begin{array}{l}218.2 \\
(15.4)\end{array}$ & $\begin{array}{r}220 \\
(16.9)\end{array}$ & $\begin{array}{l}215.4 \\
(17.2)\end{array}$ \\
\hline $\begin{array}{l}\text { S. longiotom extract } \\
(100 \mathrm{mg} / \mathrm{kg})\end{array}$ & $\begin{array}{l}216.3 \\
(16.9)\end{array}$ & $\begin{array}{r}196.7 \mathrm{a} \\
(13.8)\end{array}$ & $\begin{array}{r}119.5^{\mathrm{a}} \\
(9.6)\end{array}$ \\
\hline $\begin{array}{l}\text { S. longiotom extract } \\
(200 \mathrm{mg} / \mathrm{kg})\end{array}$ & $\begin{array}{l}215.2 \\
(19.3)\end{array}$ & $\begin{array}{r}162.9 \mathrm{a} \\
(13.8)\end{array}$ & $\begin{array}{r}109.3^{\mathrm{a}} \\
(8.4)\end{array}$ \\
\hline $\begin{array}{l}\text { Glibenclamide } \\
(5 \mathrm{mg} / \mathrm{kg})\end{array}$ & $\begin{array}{l}207.6 \\
(14.8)\end{array}$ & $\begin{array}{r}109.4^{\mathrm{a}} \\
(7.9)\end{array}$ & $\begin{array}{r}96.8^{\mathrm{a}} \\
(6.5)\end{array}$ \\
\hline
\end{tabular}

firmed 48 hours after alloxan injection by determining the plasma glucose concentration; only animals with plasma glucose of $150-200 \mathrm{mg} / \mathrm{dL}$ were used for the experiment. The diabetic animals were allowed free access to tap water and pellet diet and were maintained at room temperature in plastic cages (Dixit and Kar, 2010).

\section{Drug administration}

The quantities of the individual drug to be administered were calculated and suspended in vehicle
( $1 \% \mathrm{~W} / \mathrm{V}$ suspension of carboxymethyl cellulose (CMC) in water $10 \mathrm{~mL} / \mathrm{kg}$ body weight).

\section{Experimental group protocol}

Animals were classified into five groups of six rats each. Group I served as control and received $1 \% \mathrm{w} / \mathrm{v}$ suspension of CMC in water at a dose of $10 \mathrm{~mL} / \mathrm{kg}$ b.w. Group II treated with alloxan monohydrate $150 \mathrm{mg} / \mathrm{kg}$ served as diabetic control. Group III and IV received an ethanolic extract of S. longiotom in 1\% CMC at a dose of (100 and $200 \mathrm{mg} / \mathrm{kg}$. body weight) respectively. Group $\mathrm{V}$ treated with glibenclamide (5 mg/ $\mathrm{kg}, \mathrm{b} . \mathrm{w})$ and served as reference standard.

\section{Collection of blood samples and estimation of biochemical parameters}

At the end of the experimental periods, experimental rats were sacrificed. Plasma and serum were separated from the blood by centrifuging the samples at 5,000 rpm for $10 \mathrm{~min}$ and stored under refrigeration until analyzed. Plasma glucose was estimated before starting the treatment weekly and up to the end of treatment period (10 and 21 days). Lipid profile was estimated at the end of the study (21 day).

Glucose (Middleton, 1959; Salib et al., 2013), total cholesterol (Bowman and Wolf, 1962; Salib et al., 2013), plasma triglycerides (Nagaraju et al., 2013; Salib et al., 2013), high-density lipoprotein (HDL) cholesterol (Salib et al., 2013), serum glutamate pyruvate transaminase (Salib et al., 2013) (SGPT), serum glutamate oxaloacetate transaminase (SGOT), and alkaline phosphatase (Salib, et al., 2013) (ALP) were determined by using commercially available kits. The total protein was also estimated (Salib et al., 2013). VLDL (very low-density lipoproteins) cholesterol was calculated as: TG/5; LDL cholesterol was calculated by the equation: LDL cholesterol = TC - (HDL + VLDL). All estimations were done using the auto analyzer.

\section{Statistical analysis}

Statistical analysis was performed with SPSS 12 statistical software package. All the values were expressed as mean \pm standard error mean (SEM). Significance between the groups was estimated by students ' $t$ ' test. $\mathrm{P}$ value $<0.001$ considered as significant and the minimum level of significance was fixed at $\mathrm{p}<0.05$.

\section{Results}

The blood glucose levels in the untreated diabetic group were increased significantly $220.0 \pm 16.9$ $(p<0.001)$ when tested against the control group (Table I). After the treatment with $S$. longiotom extract, there was significant reduction of total blood glucose when compared with the diabetic control group.

Lipid profile have been estimated and compared with 


\begin{tabular}{|c|c|c|c|c|}
\hline \multicolumn{5}{|c|}{ Table II } \\
\hline \multicolumn{5}{|c|}{$\begin{array}{l}\text { Effect of ethanolic extract of S. longiotom on } \\
\text { lipid profile }\end{array}$} \\
\hline Groups & $\begin{array}{l}\text { TGL } \\
\mathrm{mg} / \\
\mathrm{dL}\end{array}$ & $\begin{array}{l}\mathrm{HDL} \\
\mathrm{mg} / \\
\mathrm{dL}\end{array}$ & $\begin{array}{c}\text { VLDL } \\
\mathrm{mg} / \\
\mathrm{dL}\end{array}$ & $\begin{array}{c}\text { LDL } \\
\mathrm{mg} / \\
\mathrm{dL}\end{array}$ \\
\hline Control & 76.7 & 48.2 & 15.3 & 23.0 \\
\hline (Normal saline) & (5.7) & (2.5) & (1.1) & (2.9) \\
\hline Diabetic control & 121.2 & 32.5 & 24.2 & 189.9 \\
\hline (Alloxan 150 mg/kg) & $(10.3)$ & $(2.7)$ & (2.1) & (12.6) \\
\hline $\begin{array}{l}\text { S. longiotom extract } \\
(100 \mathrm{mg} / \mathrm{kg})\end{array}$ & $\begin{array}{r}104.5 \\
(8.3)\end{array}$ & $\begin{array}{r}36.7 \mathrm{a} \\
(2.5)\end{array}$ & $\begin{array}{l}20.9 \\
(1.7)\end{array}$ & $\begin{array}{r}167.3^{\mathrm{a}} \\
(12.5)\end{array}$ \\
\hline $\begin{array}{l}\text { S. longiotom extract } \\
(200 \mathrm{mg} / \mathrm{kg})\end{array}$ & $\begin{aligned} 97.4^{\mathrm{a}} \\
(7.3)\end{aligned}$ & $\begin{array}{l}40.6^{\mathrm{a}} \\
(3.4)\end{array}$ & $\begin{array}{l}19.5 \\
(1.5)\end{array}$ & $\begin{array}{r}88.4^{\mathrm{b}} \\
(5.7)\end{array}$ \\
\hline $\begin{array}{l}\text { Glibenclamide } \\
(5 \mathrm{mg} / \mathrm{kg})\end{array}$ & $\begin{array}{r}113.6 \\
(6.7)\end{array}$ & $\begin{aligned} 39.8^{\mathrm{a}} \\
(2.8)\end{aligned}$ & $\begin{array}{l}22.7 \\
(1.3)\end{array}$ & $\begin{array}{r}95.8^{\mathrm{b}} \\
(2.7)\end{array}$ \\
\hline \multicolumn{5}{|c|}{$\begin{array}{l}\text { Values are expressed as mean and S.E. Within parenthesis; } n=6 \text {; } \\
\text { ap }<0.01 \text { vs control; } b p<0.001 \text { vs control by Students 't' test }\end{array}$} \\
\hline
\end{tabular}

Table III

Effect of ethanolic extract of S. longiotom on choles-terol and protein

\begin{tabular}{|lcr|}
\hline Groups & Total cholesterol & Protein \\
\cline { 2 - 3 } Control & 86.5 & 3.6 \\
(Normal saline) & $(6.5)$ & $(0.2)$ \\
Diabetic control & 246.6 & 3.7 \\
(Alloxan $150 \mathrm{mg} / \mathrm{kg})$ & $(17.4)$ & $(0.4)$ \\
S. longiotom extract & $167.3^{\mathrm{a}}$ & 3.5 \\
$(100 \mathrm{mg} / \mathrm{kg})$ & $(12.5)$ & $(0.6)$ \\
S. longiotom extract & $148.4^{\mathrm{a}}$ & 2.9 \\
$(200 \mathrm{mg} / \mathrm{kg})$ & $(10.6)$ & $(0.2)$ \\
Glibenclamide & $158.3^{\mathrm{b}}$ & 2.8 \\
$(5 \mathrm{mg} / \mathrm{kg})$ & $(6.8)$ & $(0.5)$ \\
Values are expressed as mean and SE is within parenthesis; $\mathrm{n}=6 ;$ \\
a $\mathrm{p}<0.01$ vs control; b $\mathrm{p}<0.001$ vs control by Students ' $\mathrm{t}$ ' test \\
\hline
\end{tabular}

Table IV

Effect of ethanolic extract of S. longiotom on SGOT, SGPT and ALP

\begin{tabular}{|c|c|c|c|}
\hline Groups & $\begin{array}{l}\text { SGOT } \\
(\mathrm{U} / \mathrm{L})\end{array}$ & $\begin{array}{l}\text { SGPT } \\
(\mathrm{U} / \mathrm{L})\end{array}$ & $\begin{array}{l}\text { ALP } \\
(\mathrm{IU} / \mathrm{L})\end{array}$ \\
\hline $\begin{array}{l}\text { Control } \\
\text { (Normal saline) }\end{array}$ & $\begin{array}{l}96.5 \\
(2.8)\end{array}$ & $\begin{array}{l}36.3 \\
(1.5)\end{array}$ & $\begin{array}{l}15.9 \\
(0.7)\end{array}$ \\
\hline $\begin{array}{l}\text { Diabetic control } \\
\text { (Alloxan } 150 \mathrm{mg} / \mathrm{kg} \text { ) }\end{array}$ & $\begin{array}{r}117.3^{a} \\
(8.6)\end{array}$ & $\begin{array}{r}53.2^{\mathrm{a}} \\
(4.8)\end{array}$ & $\begin{array}{r}33.5^{\mathrm{b}} \\
(3.7)\end{array}$ \\
\hline $\begin{array}{l}\text { S. longiotom extract } \\
(100 \mathrm{mg} / \mathrm{kg})\end{array}$ & $\begin{array}{r}103.5^{\mathrm{a}} \\
(7.6)\end{array}$ & $\begin{array}{l}41.9 \mathrm{a} \\
(3.5)\end{array}$ & $\begin{array}{l}28.4 \\
(3.2)\end{array}$ \\
\hline $\begin{array}{l}\text { S. longiotom extract } \\
(200 \mathrm{mg} / \mathrm{kg})\end{array}$ & $\begin{array}{r}98.3^{\mathrm{a}} \\
(9.4)\end{array}$ & $\begin{array}{l}39.8 \\
(3.2)\end{array}$ & $\begin{array}{r}21.5^{\mathrm{b}} \\
(1.9)\end{array}$ \\
\hline $\begin{array}{l}\text { Glibenclamide } \\
(5 \mathrm{mg} / \mathrm{kg})\end{array}$ & $\begin{array}{l}99.3 \\
(6.4)\end{array}$ & $\begin{array}{l}40.4 \\
(3.2)\end{array}$ & $\begin{array}{l}19.5 \\
(1.4)\end{array}$ \\
\hline
\end{tabular}

treated, untreated and control groups of rats (Table II). There was a significant increase in the values of TG, VLDL cholesterol, LDL cholesterol and decrease in HDL cholesterol in the untreated diabetic control rats compared to standard. After the treatment with 100 and
$200 \mathrm{mg} / \mathrm{kg}$ of ethanolic extract of S. longiotom, there was significant reduction in these values, when the dose is increased there was a linear reduction in the amount of TG and VLDL cholesterol and LDL cholesterol. HDL cholesterol level has been raised in the treated groups. This reveals that the ethanolic extract of $S$. longiotom acts as a stimulator for lipid degradation and to increase the concentration of good cholesterol which is used to reduce the risk of hypercholesterolemia.

Total cholesterol levels in the untreated diabetic group were increased $246.6 \pm 17.4$ significantly $(p<0.01)$ when tested against the control group (Table III). After the treatment with $S$. longiotom extract, the reduction of total cholesterol and the protein level $148.4 \pm 10.6$ was significant at $(\mathrm{p}<0.001)$ and the mean values are comparable with that of the control groups.

SGOT, SGPT and ALP are considered as very important metabolic enzymes. The levels of SGOT, SGPT and ALP have been compared with treated and untreated diabetic rats (Table IV). The enzyme levels are gradually increased in the untreated diabetic rats when compared to control. The values of SGOT, SGPT and ALP have been significantly reduced in the treated animals when compared to standard. There is no difference between standard and $S$. longiotom extracts $(200 \mathrm{~g} / \mathrm{kg})$ against the level of these enzymes.

\section{Discussion}

Diabetes mellitus is a chronic disorder caused by partial or complete insulin deficiency. It produces an inadequate glucose control and leads to acute and chronic complications (Ikewuchi et al., 2011). Alteration in the serum lipid profile is known to occur in diabetes and this is likely to increase the risk of cardiovascular disease (Hamden et al., 2009). The lowering of plasma glucose and lipid levels through dietary modification and drug therapy seems to be associated with a decrease in the risk of vascular disease (de Sousa et al., 2004).

Alloxan, selective beta cytotoxin, induces "chemical diabetes" in many animal species by damaging the insulin-secreting cells of the pancreas (Bilic, 1975) and the animals became permanently diabetic (Bilic, 1975). However, these animals have existing beta cells and regeneration is possible. It is well known that the glibenclamide act by directly stimulating the beta cells of the Islets of Langerhans to release more insulin and these compounds are active in mild alloxan induced diabetes (Kumar et al., 2013). Since the present findings show that glibenclamide decreased the glucose, TC, TG, LDL cholesterol, VLDL cholesterol, SGOT, SGPT, ALP levels and increase in HDL cholesterol level in the diabetic animals, the extent of diabetes is not severe.

In the present study, treatment with ethanolic extract of 
S. longiotom in alloxan induced diabetic rats produced a more significant decrease in blood glucose level. The hypoglycemic effect may be due to increased secretion of insulin from the beta cells of pancreas, i.e., pancreatotrophic action (El-Alfy et al., 2005). The results were comparable to that of glibenclamide, which acts by stimulation of insulin release thus further confirming that the extract lowers blood glucose by a pancreatotrophic action.

Furthermore, S. longiotom produced significant benefitcial effects on the lipid profile in alloxan induced diabetic rats by reducing TG, TC, LDL and VLDL and increasing HDL, significantly. The ethanolic extract of $S$. longiotom may increase the secretion of insulin from beta cells of the pancreas; this increased secretion of insulin stimulates fatty acid biosynthesis and also the incorporation of fatty acids into TG in the liver and adipose tissue. In the present study the decrease of TC, TG and LDL cholesterol levels achieved by administration of leaf extract, demonstrates a possible protection against hypercholesterolemia (Salib et al., 2013).

Moreover the ethanolic extract of $S$. longiotom caused a significant reduction in the levels of SGOT, SGPT and ALP. The activity of SGOT, SGPT and ALP are cytosolic marker enzymes reflecting hepatocellular necrosis as they are released into the blood after cell membrane damage. By the reduction of these enzymes in the diabetic rats suggesting that the extract of $S$. longiotem may prevent hepatic injury associated with diabetes.

From overall study, it is concluded that the ethanolic extract of $S$. Longiotom showed a significant hypoglycemic and hypolipidemic activity in the model of of alloxan-induced diabetic rats. There were no toxic effects during this period in regards to hepatotoxicity. Therefore, the ethanolic extract of the seaweed $S$. longiotem can be used as an alternative treatment for diabetes.

\section{References}

Alberti KG, Zimmet PZ. Definition, diagnosis and classification of diabetes mellitus and its complications. Part 1: Diagnosis and classification of diabetes mellitus provisional report of a WHO consultation. Diabet Med. 1998; 15: 539-53.

Aravindan S, Delma CR, Thirugnanasambandan SS, Herman TS, Aravindan N. Anti-pancreatic cancer deliverables from sea: First-hand evidence on the efficacy, molecular targets and mode of action for multifarious polyphenols from five different brown-algae. PLoS One 2013; 8: e61977.
Bilic N. The mechanism of alloxan toxicity: An indication for alloxan complexes in tissues and alloxan inhibition of 4acetamido-4'-isothiocyanato-stilbene-2,2'-disulphonic acid (SITS) binding for the liver cell membrane. Diabetologia 1975; 11: 39-43.

Bowman RE, Wolf RC. A rapid and specific ultramicro method for total serum cholesterol. Clin Chem. 1962; 8: 302-09.

de Sousa E, Zanatta L, Seifriz I, Creczynski-Pasa TB, Pizzolatti MG, Szpoganicz B, Silva FR. Hypoglycemic effect and antioxidant potential of kaempferol-3,7-O-(alpha)-dirhamnoside from Bauhinia forficata leaves. J Nat Prod. 2004; 67: 82932.

Dembinska-Kiec A, Mykkanen O, Kiec-Wilk B, Mykkanen H. Anti-oxidant phytochemicals against type 2 diabetes. $\mathrm{Br} \mathrm{J}$ Nutr. 2008; 99 (E Suppl 1): ES109-17.

Dixit Y, Kar A. Protective role of three vegetable peels in alloxan induced diabetes mellitus in male mice. Plant Foods Hum Nutr. 2010; 65: 284-89.

El-Alfy AT, Ahmed AA, Fatani AJ. Protective effect of red grape seeds proanthocyanidins against induction of diabetes by alloxan in rats. Pharmacol Res. 2005; 52: 264-70.

Guerra Dore CM, Faustino Alves MG, Santos ND, Cruz AK, Camara RB, Castro AJ, Guimaraes Alves L, Nader HB, Leite EL. Antiangiogenic activity and direct antitumor effect from a sulfated polysaccharide isolated from seaweed. Microvasc Res. 2013; 88: 12-18.

Hamden K, Allouche N, Damak M, Elfeki A. Hypoglycemic and anti-oxidant effects of phenolic extracts and purified hydroxytyrosol from olive mill waste in vitro and in rats. Chem Biol Interact. 2009; 180: 421-32.

Ikewuchi JC, Onyeike EN, Uwakwe AA, Ikewuchi CC. Effect of aqueous extract of the leaves of Acalypha wilkesiana 'Godseffiana'Muell Arg (Euphorbiaceae) on the hematology, plasma biochemistry and ocular indices of oxidative stress in alloxan induced diabetic rats. J Ethnopharmacol. 2011; 137: $1415-24$

Kumar S, Sharma S, Vasudeva N. Screening of antidiabetic and antihyperlipidemic potential of oil from Piper longum and piperine with their possible mechanism. Expert Opin Pharmacother. 2013; 14: 1723-36.

Middleton JE. Experience with a glucose-oxidase method for estimating glucose in blood and CSF. Br Med J. 1959; 1 (5125): 824-26.

Nagaraju R, Joshi AKR, Rajini PS. Estimation of plasma triglycerides with correction for free glycerol by orlistat inhibition of lipoprotein lipase activity. Analy Biochem. 2013; 439: 4446.

Salib JY, Michael HN, Eskande EF. Anti-diabetic properties of flavonoid compounds isolated from Hyphaene thebaica epicarp on alloxan induced diabetic rats. Pharmacog Res. 2013; 5: 22-29. 